University of Nebraska - Lincoln

DigitalCommons@University of Nebraska - Lincoln

\title{
Recent Advances in Global Lake Coring Hold Promise for Global Change Research in Paleolimnology
}

Walter E. Dean

U.S. Geological Survey, Denver, CO, dean@usgs.gov

Follow this and additional works at: https://digitalcommons.unl.edu/usgsstaffpub

Part of the Earth Sciences Commons

Dean, Walter E., "Recent Advances in Global Lake Coring Hold Promise for Global Change Research in Paleolimnology" (2010). USGS Staff -- Published Research. 308.

https://digitalcommons.unl.edu/usgsstaffpub/308

This Article is brought to you for free and open access by the US Geological Survey at DigitalCommons@University of Nebraska - Lincoln. It has been accepted for inclusion in USGS Staff -- Published Research by an authorized administrator of DigitalCommons@University of Nebraska - Lincoln. 


\title{
Recent advances in global lake coring hold promise for global change research in paleolimnology
}

\author{
Walter E. Dean
}

Received: 26 February 2010/Accepted: 29 March 2010/Published online: 11 April 2010

(C) US Government 2010

Thank you, Antje, for your generous comments and I thank IPA for presenting me with this award along with three giants of paleolimnology! I am humbled and delighted to accept this award as a representative of all those in the Paleolimnology community whose creative insights continue to make Paleolimnology inspiring.

As all paleolimnologists know, the key to any paleolimnology study starts with obtaining a good core. To that end, it is significant that all paleolimnlogists owe a debt of gratitude to two men being honored here today, Dan Livingstone and Herb Wright. Because most paleolimnology studies are interested in Holocene records, the Livingstone piston corer and the square-rod modified versions are adequate for this purpose. These devices have been the main weapons in paleolimnological research, obtaining cores of up to $20 \mathrm{~m}$ long-if you're lucky. Because I have one foot in paleolimnology and one foot in paleoceanography, I have also had to rely on another piston corer, modifications of the Swedish Kullenberg piston corer, also obtaining

The author was the recipient of a "Lifetime Achievement Award" presented by the International Paleolimnology Association (IPA) in Guadalajara, Mexico on 16 December 2009

W. E. Dean $(\bowtie)$

US Geological Survey, MS 980 Federal Center,

Denver, CO, USA

e-mail: dean@usgs.gov cores of up to $20 \mathrm{~m}$ long-if you're lucky, perhaps going back tens of thousands of years. The dominant archive of Quaternary paleoceanographic records resides in cores taken daily for years by Lamont Doherty's ships Vema and Robert Conrad all over the world. To get longer records, the paleoceanographic community solved the problem in 1968 with the Glomar Challenger and the Deep Sea Drilling Project (DSDP), and later the Joides Resolution and the Ocean Drilling Program (ODP), obtaining records going back to the Jurassic using rotary drilling. Unfortunately this made soup of Quaternary records. I have been involved with a number of lake drilling projects using rotary drilling rigs with the same results; we would get great Miocene records, but lousy Quaternary records. The Paleoceanography community solved this problem in 1978 with the hydraulic piston corer.

In 1978 I was at a post-cruise DSDP meeting at Scripps Institute of Oceanography in La Jolla, CA. Kerry Kelts, then still a graduate student at Zurich, but on loan to DSDP as a staff representative, had just gotten off the Glomar Challenger after having taken the first hydraulic piston core at Site 480 in the Gulf of California. Drinking beer at a TGIF at Scripps, Kerry and I talked about this and asked ourselves, "when are we going to have that capability for lakes?" Kerry, along with Steve Colman and others, started the ball rolling over the next couple decades. Engineering expertise was sought from Drilling Observation and Sampling of the Earth's Continental 
Crust (DOSECC) in Salt Lake City, Utah, and the International Continental Drilling Program (ICDP) in Potsdam, Germany.

Finally, to assess the need for long continental records, a workshop was held in Potsdam, Germany, in 1995. The engineers wanted to put a rotary drilling rig on a barge to take hundreds of meters of core costing millions of dollars and not being very transportable. The participants in the Potsdam workshop organized a Lake Drilling Task Force to assess the potential for lake drilling. Proposals were solicited and compiled into a 5-year drilling plan that was presented at the International Continental Drilling Symposium in 1996 in Japan, and the plan was submitted to ICDP as a "Prospectus for a Global Lake Drilling Initiative." And so the concept of Global Lake Drilling (GLAD) was born. Now all that was needed was that lake-going Joides Resolution. We said to the engineers, "Look, we want a platform and drill rig that can collect a sequence of cores of lake sediments ranging in total length from 20 to $200 \mathrm{~m}$, using highly transportable equipment costing less than one million dollars." And so the concept of GLAD200 was born (Global Lake Drilling to $200 \mathrm{~m}$ ), and the DOSECC engineers were in charge of designing the rig.
The engineers came to a group of us at a meeting at the Limnological Research Center (LRC) in Minneapolis in 1998. They said "Look, if we can build a rig to get $200 \mathrm{~m}$ of core, we can probably build a rig to handle a total drill string length (water plus sediment) of $800 \mathrm{~m}$ for under a million dollars." From this meeting, the concept of GLAD800 emerged. A proposal-writing workshop was hosted by the USGS in Denver in December 1998, and a proposal was submitted to ICDP in January 1999, to fund the construction of the GLAD800 platform. The final design consisted of eight 20-foot-long standard international shipping containers that are made in China. They come over here loaded with Chinese goods, and are stockpiled in ports like Long Beach. The containers are locked together at the corners, have a layer of foam at the top of each container, a layer of water on the bottom, and an airbag in between that can be inflated or deflated to adjust the trim of the platform (Fig. 1). The drill rig is a modified Christensen coring rig. Drilling tools, including a hydraulic piston corer, are standard ODP wireline tools. Core barrels are 10-ft (3-m) long and use standard ODP plastic liners. This design was approved, and funding was recommended by ICDP in December 1999. The platform was built in

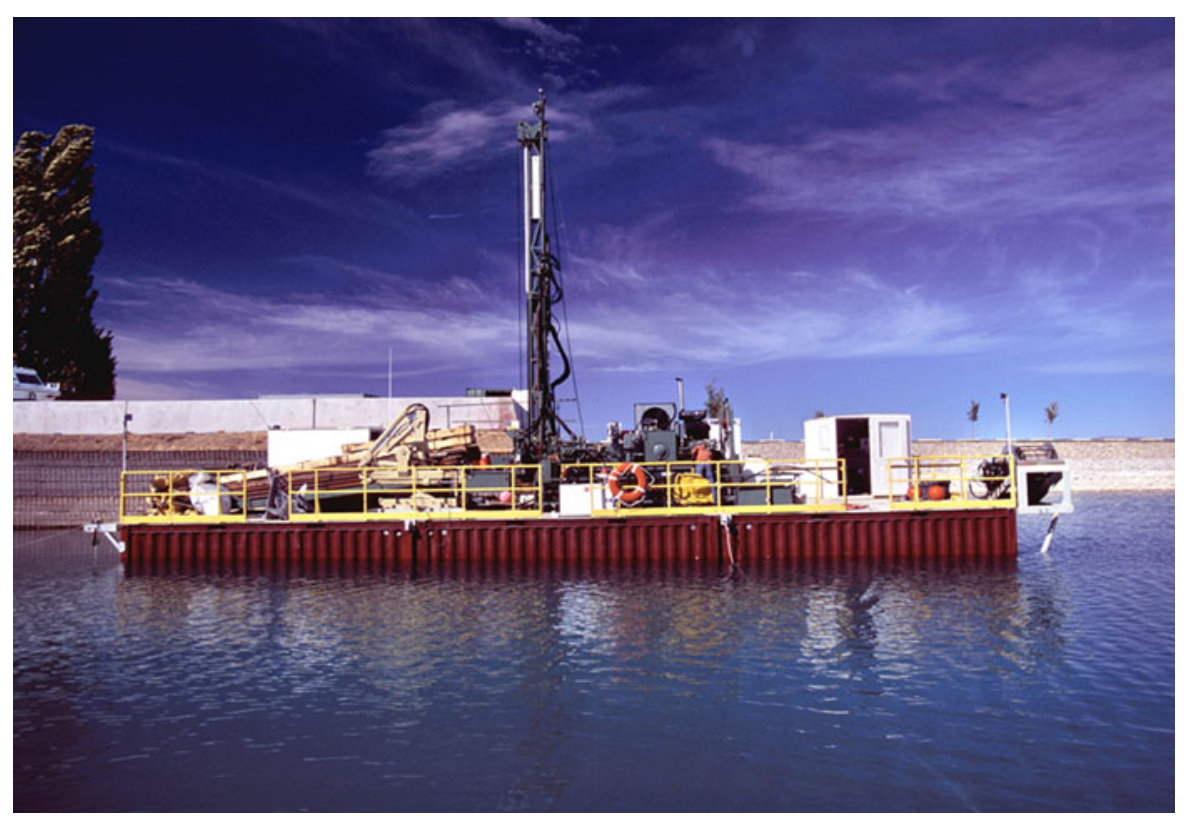

Fig. 1 The GLAD800 drill rig and platform (R/V Kerry Kelts) at the Bear Lake Marina, Garden City, Utah 


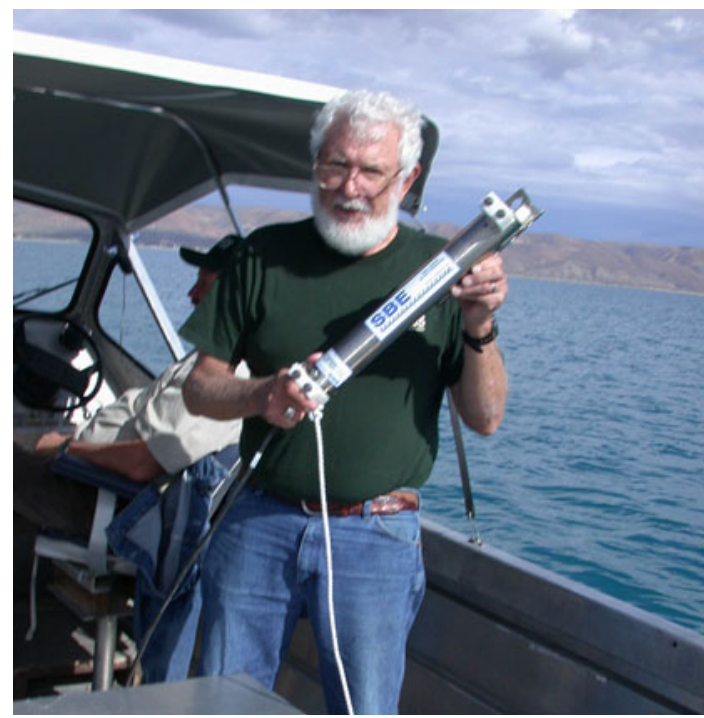

Fig. 2 Walt Dean running CTD profiles in Bear Lake, Utah and Idaho

Rexburg, Idaho in 2000 and tested on Great Salt Lake, Utah, and Bear Lake, Utah and Idaho (Fig. 2) in August and September 2000, with funding from NSF and USGS (Fig. 1; Dean et al. 2002). The DOSECC Board of Directors decided to call the GLAD800 rig the RV Kerry Kelts, and since then it has been all over the world (Fig. 1).

In closing, I would like to pay tribute to a good friend and colleague of mine for over 40 years, John Platt Bradbury, who made considerable contributions to paleolimnology. Several years ago, John Smol asked some of us to give him some of our thoughts on the "state of the art" of paleolimnology. Platt responded with a long e-mail letter. Those of you who knew Platt, either as John, J. Platt, or Platt, know that he could be quite caustic. I'd like to provide you with a few of his comments, which I call "Plattatudes":

"You got to have a lot of buddies to help you understand the data and steer you through the maze of most probable interpretations" (Platt's way of saying you gotta be multiproxy).

"It is amazing how little most paleolimnologists understand about limnology. Unfortunately, often many don't even seem to care."

"Most limnologists are as dumb about hydrology as we are about limnology" (notice that he includes himself in that).

"How much money goes into to training of isotope geochemists and the making and running of their machines to produce lake records that are essentially meaningless at worst, or interpretable only in the theoretical or logical context of another proxy?" (Those of you who heard Antje Schwalb's and my plenary talks know that we do not necessarily share Platt's view. However, I do think that if stable isotopes are your only proxies, you are in trouble). On that note I'll close with a warm thank you to the IPA Executive Board.

\section{Reference}

Dean W, Rosenbaum J, Haskell B, Kelts K, Schnurrenberger D, Valero-Garcés B, Cohen A, Davis O, Dinter D, Nielson D (2002) Progress in global lake drilling holds potential for global change research. EOS (Trans Am Geophys Union) 83(9):85, 90, 91 